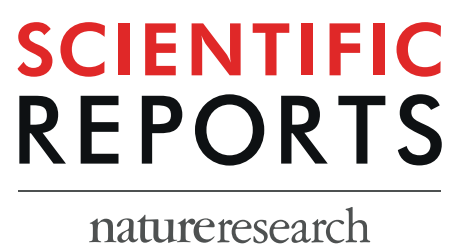

\title{
OPEN A comparative study on flavour components and therapeutic properties of unfermented and fermented defatted soybean meal extract
}

\begin{abstract}
Kadry Z. Ghanem ${ }^{1,6}$, Mohamed Z. Mahran ${ }^{2,6}$, Manal M. Ramadan ${ }^{3}$, Hassan Z. Ghanem ${ }^{4}$, Mohamed Fadel ${ }^{5}$ \& Mohamed H. Mahmoud (10) ${ }^{1,7 *}$

Microbial fermentation of plant material alters the composition of volatile and non-volatile plant natural products. We investigated the antioxidant, anticancer, and antiviral properties of extracts of defatted soybean meal fermented with Aspergillus fumigatus F-993 or A. awamori FB-133 using in vitro methods. Gas chromatography-mass spectrometry analysis of soybean meal fermented with A. awamori FB-133 and A. fumigatus F-993 identified 26 compounds with 11,14-octadecadienoic acid and methyl ester (63.63\%) and 31 compounds with butylated hydroxytoluene $(66.83 \%)$ and $\delta$-myrcene $(11.43 \%)$ as main constituents, respectively. The antioxidant activities of DSM extract were $3.362 \pm 0.05$ and $2.11 \pm 0.02 \mathrm{mmol}$ TE $/ \mathrm{mL}$, FDSM treated with $A$. awamori FB- 133 were $4.763 \pm 0.05$ and $3.795 \pm 0.03 \mathrm{mmolTE} / \mathrm{mL}$ and FDSM treated with $A$. fumigatus F-993 were $4.331 \pm 0.04$ and $3.971 \pm 0.02 \mathrm{mmol} \mathrm{TE} / \mathrm{mL}$ as determined by ABTS and FRAP assays, respectively. Both fermented extracts had better antioxidant activity than the unfermented extract as shown by multiple antioxidant activity assays. The concentration of fermented extracts required for $50 \%$ inhibition of cell viability was significantly lower than that of the unfermented extract when tested against the human liver cancer cell line HepG2 as shown by cell viability assays, indicating strong anticancer activity. The $\mathrm{IC}_{50}$ values for DSM, FDSM with A. fumigatusF-993 and FDSM with A. awamori FB-133 were27, 16.88 and 8.60 $\mu \mathrm{g} / \mathrm{mL}$, respectively. The extract of FDSM with $A$. awamori FB-133 showed the strongest anticancer activity, compared to DSM and FDSM with $A$. FumigatusF-993 extracts. Fermented extracts also reduced hepatitis $A$ virus titres to a greater extent than unfermented extracts, thus showing strong antiviral property. Hepatitis $A$ virus titres were reduced by 2.66 and $3 \log _{10} / 0.1 \mathrm{~mL}$ by FDSM with $A$. fumigatusF-993 and FDSM by A.awamori FB-133, respectively, compared to DSM $\left(5.50 \log _{10} / 0.1 \mathrm{~mL}\right)$. Thus, the fermentation of soybean meal with A. fumigatusF-993 or A. awamori FB-133 improves the therapeutic effect of soybean extracts, which can be used in traditional medicine.
\end{abstract}

Fermentation of plant materials causes a significant change in bioactive volatile and non-volatile components ${ }^{1}$. Moreover, the concentrations of both flavonoids and the unsaturated fatty acid esters, as well, increase due to the fermentation of soybean. Extracts of fermented soybean have shown strong antioxidant, anti-breast cancer and antiviral activities ${ }^{2}$. A growing major objective interest is to develop special catalytic systems (one-pot tandem), that integrate both the reactivity of a chemical catalyst and a selected active site of an enzyme $e^{3}$. Fungi (as yeasts,

\footnotetext{
${ }^{1}$ Nutrition and Food Science Department, National Research Centre, Dokki, Giza, Egypt. ${ }^{2}$ Nutrition and Food Sciences Department, Faculty of Home Economics, Menufyia University, Menufyia, Egypt. ${ }^{3}$ Chemistry of Flavour and Aroma Department, National Research Centre, Dokki, Giza, Egypt. ${ }^{4}$ Therapeutical Chemistry Department, National Research Centre, Dokki, Giza, Egypt. ${ }^{5}$ Microbial Chemistry Department, National Research Centre, Dokki, Giza, Egypt. ${ }^{6}$ Clinical Nutrition Department, Faculty of Applied Medical Sciences, Jazan University, Jazan, Kingdom of Saudi Arabia. ${ }^{7}$ Deanship of Scientific Research, King Saud University, Riyadh, Saudi Arabia. *email: mmahmoud2@ ksu.edu.sa
} 
moulds), bacteria and several microorganisms are known to produce lipases that digest lipids. Moreover, fungal lipases are used as industrial catalysts to resolve racemic alcohols used for preparing some prostaglandins, steroids, and carboxylic nucleoside analogues. Such lipases also catalyse the hydrolysis of short chain triglycerides, which represent very good substrates for lipases. In addition, proteases and amylases, which catalyse the hydrolysis of proteins and carbohydrates respectively, are widely used in different industries. Recently, the biocatalytic potential of microbial lipases, in both aqueous and non-aqueous media, have encourage many industries to utilize these enzymes in a variety of great important reactions, especially organic synthesis reactions. The region selective nature of lipases are used for different purposes such as, fat modification, butter constituents, biofuels, synthesis of personal care products, the resolution of chiral drugs, flavour enhancers and synthesize of cocoa. Therefore, pharmacists, biophysicists, organic chemists, biochemists, biotechnologists, microbiologists and process engineers are now widely using lipases ${ }^{4}$. Although, soybeans are commonly rich in phenolics (e.g. flavanols, flavanones, phenolic acids, other phenolic compounds), yet isoflavones are the most abundant. However, such compounds can be modified through fermentation for improved antioxidant activities ${ }^{5}$. Fermentation of soybean with filamentous fungi has been reported to enhance their phenolic content and radical scavenging activity ${ }^{6}$. However, the antiviral activity of fermented soybean, for the treatment of viral diseases infecting human intestines, is not yet examined. Soybean fermentation can be done by using a number of microorganisms, for example fungi (as filamentous types) bacteria (as Bacillus sp. and lactic acid bacteria). Many fungal species, such as A. awamori, are commonly used for the production of many in fermented foods and flavours ${ }^{7,8}$ fermentation of soybean with Aspergillus oryzae increased its antioxidant activity ${ }^{9}$. Some Lactobacillus spp. and Bifidobacterium spp. have been reported to $\beta$-glucosides and enhance the isoflavone bioavailability by fermentation ${ }^{10,11}$. Several researchers have recommended the use of solid state fermentation method "SSF" for the production many bacterial and fungal metabolites, using different substrates ${ }^{1,6,12}$.

Cancer refers to the development of abnormal cells characterized by autonomous growth and loss of differentiation $^{13}$. The American Cancer Society estimates the probable numbers of new cancer cases and deaths in the United States of America annually and compiles data on cancer incidence, mortality, and survival ${ }^{14}$. However, chemotherapy is often accompanied by adverse effects, which prolongs patient recovery ${ }^{13}$. Recently, there has been a more growing interest in the large-scale industrial utilization of biocatalysts in the production of fine chemicals and medicinal compounds ${ }^{15}$. In recent years, plant products such as flavonoids, terpenoids, and alkaloids have been studied for their varied pharmacological properties including antioxidant activity against free radicals that can cause cancer, inflammation, and diabetes ${ }^{16}$. The high concentrations of both polyphenols and volatile constituents in plant extracts account for their higher antioxidant activity ${ }^{17-19}$. Recently, plant extracts have been screened for anticancer activity to identify novel therapeutic strategies against cancer ${ }^{20-22}$.

The major causative pathogens of foodborne illness are viruses, followed by bacteria and parasites ${ }^{23}$. Several pure and crude plant derivatives and extracts are now being used as novel antimicrobial and/or antiviral against herpes simplex virus type 1 (HSV-1) infections ${ }^{24}$. In the present times, the anti-HSV-1 potential of plant extracts including phenolic compounds, polyphenols, peptides, isoprenoidal glycosides, pyranocoumarins and benzophenones have been evaluated ${ }^{25}$. Several fungal species of the genus Aspergillus, e.g. A. niger and A. phoenicus were found to increase b-glucosidase enzyme (BGL) yield, which plays a key role in biomass hydrolysis by producing monomeric sugars from cellulose-based oligosaccharides ${ }^{12}$. In view of the above facts, the present study evaluates the efficiency of A. fumigatus F-993 and A. awamori FB-133 in bioactive compound production from soybean meal and the antioxidant, anticancer, and antiviral potentials of the ethanolic extracts of defatted soybean meal (DSM) fermented by A. fumigatus F-993 or A. awamori FB-133.

\section{Methods}

Raw material and chemicals. Defatted soybean. Egyptian defatted soybean was obtained from the Department of Medicinal and Aromatic Plants, Ministry of Agriculture, Cairo, Egypt.

Microorganisms and culture conditions. Non mycotoxin producing two fungi namely A. fumigates F-993 and A. awamori FB-133 were obtained from Microbial Chemistry Laboratory (National Research Centre, Dokki, Cairo, Egypt) and cultured on potato dextrose agar slants at $30^{\circ} \mathrm{C}$ for $72 \mathrm{~h}$. The spore suspensions were prepared by adding $10 \mathrm{~mL}$ sterile water to slant cultures and gently scraping the culture with a sterile wire loop.

Fermentation of defatted soybean. The fermentation was carried out under solid state fermentation in $250 \mathrm{~mL}$ Erlenmeyer flasks containing $5 \mathrm{~g}$ of defatted soybean moistened to $50 \%$ with distilled water and inoculated with $1 \mathrm{~mL}$ spore suspension $\left(10^{6}\right.$ spores). The cultures were incubated at $30^{\circ} \mathrm{C}$ for 3 days for solid state fermentation $^{24}$.

Defatted soybean extraction. Volatile compounds were extracted from fermented defatted soy bean DSM samples according to previously reported protocols with some modification $s^{25,26}$. The DSM and fermented DSM (FDSM) samples were ground individually to a powder using a coffee bean blender. Five grams of the ground powder was transferred into a $25 \mathrm{~mL}$ test tube and extracted with $15 \mathrm{~mL}$ ethanol. The supernatant was separated from the residue by centrifuging at $2000 \times g$ for $10 \mathrm{~min}$ in a centrifuge and transferred to a clean test tube. The residue was re-extracted with $15 \mathrm{~mL}$ ethanol; the separated ethanol layers were combined, and dried using a vacuum evaporator at less than $50^{\circ} \mathrm{C}$. The dried soybean extract was weighed and stored at $-20^{\circ} \mathrm{C}$.

Gas chromatography-mass spectrometry (GC-MS) analysis. About $2 \mu$ lof each extract was used for GC-MS analysis using a HP 5890 GC coupled to HP5970 MS. The MS was set to an ionization voltage of $70 \mathrm{eV}$ and the mass range of $\mathrm{m} / \mathrm{z} 39-400 \mathrm{amu}$ was scanned. The GC oven temperature was maintained initially at $50^{\circ} \mathrm{C}$ for $5 \mathrm{~min}$ and then programmed to rise to $250^{\circ} \mathrm{C}$ at a rate of $4{ }^{\circ} \mathrm{C} / \mathrm{min}$. Helium was used as the carrier gas at a flow rate of $1.1 \mathrm{~mL} / \mathrm{min}$. The injector and detector temperatures were set to 220 and $250^{\circ} \mathrm{C}$, respectively. The isolated 
peaks were identified by matching mass spectra with data in the National Institute of Standard and Technology library. Quantitation was carried out by peak area integration.

Determination of antioxidant activity. 2,2-Diphenyl-1-picrylhydrazyl (DPPH) assay. The DPPH assay was performed according to a previously reported protocol ${ }^{27}$. The antioxidant activity was determined by a calibration curve prepared with ascorbic acid and expressed as $\mathrm{mg}$ of ascorbic acid equivalent (AAE)/mL of sample ${ }^{28}$.

2,2'-Azino-bis (3-ethylbenzothiazoline-6-sulfonic acid) (ABTS) assay. The ABTS assay was performed as described previously ${ }^{29}$ and expressed in $\mathrm{mMof}$ Trolox equivalents (TE)/mL of extract. When the measured ABTS value was over the linear range of the standard curve, values of additional dilutions were recorded ${ }^{30}$.

Ferric reducing antioxidant power (FRAP) assay. The FRAP assay was performed according to the Benzie and Strain method, and expressed in $\mathrm{mM} \mathrm{TE} / \mathrm{mL}$ extract. Values of additional dilutions were measured when the FRAP value was over the linear range of the standard curve ${ }^{9}$.

Anticancer activity. Cell culture and treatments. Human liver cancer cell lineHepG2 was obtained from the American Type Culture Collection (Rockville, MD, USA). Cells were grown in RPMI-1640 medium supplemented with $10 \%$ foetal bovine serum, $1 \%$ MEM non-essential amino acid solution, and $1 \%$ penicillin streptomycin solution $(10,000$ units of penicillin and $10 \mathrm{mg}$ of streptomycin in $0.9 \%(\mathrm{NaCl})$ in a humidified atmosphere having $5 \% \mathrm{CO}_{2}$ at $35^{\circ} \mathrm{C}$. The passage number range was maintained between 20 and 25 . The cells were cultured in $75 \mathrm{~cm}^{2}$ cell culture flasks. For experimental purposes, the cells were cultured in 96 -well plates $(0.2 \mathrm{~mL}$ of cell solution/well). The optimum cell concentration, as determined by the cell line growth profile, was $2 \times 10^{5} \mathrm{cells} / \mathrm{mL}$. The cells were allowed to attach for $24 \mathrm{~h}$ prior to treatment with the extracts. The stock solution of each extract was filtered with $0.22 \mu \mathrm{m}$ Minisart Filters (Sigma-Aldrich) before applying to cells. To test toxicity, 11 dilutions of each extract were tested by addition to cell monolayers washed with phosphate buffer saline $(\mathrm{PBS})^{10}$.

3-(4,5-Dimethyl-2-thiazolyl)-2,5-diphenyl-2H-tetrazolium bromide (MTT) assay. The MTT assay was performed using the protocol described previously ${ }^{13}$. Briefly, the cells were incubated for $4 \mathrm{~h}$ with $0.8 \mathrm{mg} / \mathrm{mL}$ of MTT dissolved in serum-free medium. After washing with $1 \mathrm{~mL}$ PBS, $1 \mathrm{~mL}$ DMSO was added and gently shaken for $10 \mathrm{~min}$ for complete dissolution. Aliquots $(200 \mu \mathrm{L})$ of the resulting solution were transferred into 96 -well plates and absorbance was recorded at $560 \mathrm{~nm}$ using the SpectraMax ${ }^{\circledR} 190$ Microplate Reader (Molecular Devices). The concentration required for $50 \%$ inhibition of cell viability $\left(\mathrm{IC}_{50}\right)$ was calculated as described ${ }^{3}$.

Antiviral assay. Cells and viruses. Vero and BHK-21 cells were grown in Eagle's minimal essential medium (MEM, GIBCO) containing 5\% inactivated calf serum and $50 \mathrm{mg} / \mathrm{mL}$ gentamicin. Maintenance medium at $\mathrm{pH}$ 7.5 consisted MEM supplemented with $1.5 \%$ inactivated calf serum and gentamicin. The vesicular stomatitis virus (VSV) was propagated in Vero cells. Virus stocks were plaque-assayed on Vero cells as described ${ }^{31}$.

Cytotoxicity assay. Vero cells grown in 96-well tissue culture plates were incubated with 12 concentrations $(\mu \mathrm{g} / \mathrm{mL})$ of each extract for $24 \mathrm{~h}$ at $37^{\circ} \mathrm{C}$. Cell viability was measured with the MTT assay. The cytotoxicity of each extract was expressed as the $50 \%$ cytotoxic concentration $\left(\mathrm{CC}_{50}\right)$, which is the concentration required to reduce cell viability to $50 \%$ of the control ${ }^{32}$.

Statistical analysis. The results are reported as mean \pm standard deviation (SD) for at least three experiments. Statistical differences were analysed by the one-way ANOVA test.

\section{Results}

GC-MS analysis of FDSM. GC-MS analysis of extract of DSM fermented with A. fumigatus F-993(FDSM1) identified 31 compounds, of which butylated hydroxytoluene $(66.83 \%)$ and $\delta$-myrcene $(11.43 \%)$ were the main constituents (Table 1). In the GC-MS analysis of extract of DSM fermented with A. awamori FB-133 (FDSM2), 26 compounds were identified, of which 11,14-octadecadienoic acid and methyl ester (63.63\%) was the main constituents (Table 2).

Antioxidant activity. The mean values of the antioxidant activity measured for DSM, FDSM1, and FDSM2 are presented in Table 3. The antioxidant activity of DSM extract was $3.362 \pm 0.05$ and $2.11 \pm 0.02 \mathrm{mmol} \mathrm{TE} / \mathrm{mL}$ as determined by ABTS and FRAPS assays, respectively, and $0.511 \pm 0.01 \mathrm{mg}$ AAE/mL with the DPPH assay. The antioxidant activity of FDSM2 extract was $4.763 \pm 0.05$ and $3.795 \pm 0.03 \mathrm{mmolTE} / \mathrm{mL}$ with ABTS and FRAPS assays, respectively, and $0.625 \pm 0.02 \mathrm{mg} \mathrm{AAE} / \mathrm{mL}$ by DPPH assay. The antioxidant activity of FDSM1 extract was $4.331 \pm 0.04$ and $3.971 \pm 0.02 \mathrm{mmolTE} / \mathrm{mL}$ by ABTS and FRAP assays, respectively, and $0.692 \pm 0.01 \mathrm{mg}$ AAE/ $\mathrm{mL}$ with DPPH assay. Therefore, both FDSM extracts showed stronger antioxidant activity than the DSM extract.

Anticancer activity. Colorimetric MTT assay was used to determine the extracts' anticancer activity, utilizing human hepatic cancerous cell line "HepG2". The cytotoxic effects of DSM, FDSM2, and FDSM1 extracts, expressed $\mathrm{asIC}_{50}$, are summarized in $\mathrm{f} 4$. The $\mathrm{IC}_{50}$ values for FDSM2, FDSM1, and DSM extracts were 8.6, 16.88, and $27 \mu \mathrm{g} / \mathrm{mL}$, respectively, indicating that the FDSM extracts were more cytotoxic than the DSM extract.

Antiviral activity. Table 4 also represents the titres of hepatitis A virus expressed as $\log _{10} / 0.1 \mathrm{~mL}$. Extracts of FDSM1 showed stronger antiviral activity $\left(2.66 \log _{10} / 0.1 \mathrm{ml}\right)$ compared to that of the DSM and FDSM2 extracts (5.5 and $3 \log _{10} / 0.1 \mathrm{ml}$, respectively). The results of the present study revealed no significant differences in hepatitis A virus titres for FDSM1 and DSM extracts. 


\begin{tabular}{|c|c|c|}
\hline Identified compounds & Rt & Area\% \\
\hline 3-Tetradecanol & 5.32 & 0.49 \\
\hline Methyl-deacetyl colchicine & 6.02 & 0.57 \\
\hline $\mathrm{N}$-(butyl-1,2,3,4-tetrahydro-2-naphthyl)-hexa-methylen-imine & 6.25 & 0.65 \\
\hline [3-(2-Cyclohexylethyl)-6-cyclo-pentyl-hexyl]-benzene & 6.45 & 0.76 \\
\hline 3-Dotriacontane & 8.42 & 0.52 \\
\hline Cantaxanthin & 8.73 & 0.50 \\
\hline Butanoic acid, heptafluoro-,methylester & 8.81 & 0.52 \\
\hline 1,5,5-Trimethyl-6-[2-(2-methyl[1,3]-dioxolan-2-yl)-vinyl]-4-methylene-7-oxabicyclo-[4.1.0]-hept-2-ene & 8.86 & 0.60 \\
\hline 8-Myrcene & 10.34 & 11.43 \\
\hline 1,3-Dioxaphosphorinane-4,4,6-tri-methyl-2-phenoxy-2-oxide & 10.54 & 1.72 \\
\hline [4,5b]-imidazole,1-formyl-3-ethyl-6-ádribofuranosyl-pyrazole & 12.42 & 0.85 \\
\hline 1,1'-[3-(2-phenyl-ethylidene)-1,5-pentanediyl]-benzene & 13.49 & 0.74 \\
\hline 1,4-Benzenedicarboxylicacid,[4-(methoxy carbonyl)-phenyl]-methyl ester & 13.55 & 0.65 \\
\hline Methyl-6-oxoheptanoate & 18.59 & 0.52 \\
\hline 2(3H)-Furanone, dihydro-3,5-dimethyl & 21.61 & 0.51 \\
\hline 1,3,5-Trichloro-2,4,6-tris (4-nitro phenyl ethynyl)-benzene & 21.77 & 0.63 \\
\hline Butylated hydroxytoluene & 26.32 & 66.83 \\
\hline t-Butyl-ester of S-5'-Hydroxy dehydrothiojasmonic acid & 27.57 & 0.75 \\
\hline Ethyl iso-allocholate & 34.51 & 0.51 \\
\hline 7,8-Epoxylanostan-11-ol-3-acetoxy & 39.08 & 0.50 \\
\hline N-Methyl yunaconitine-3-ol & 44.61 & 0.58 \\
\hline$\alpha$-D-Glucopyranoside methyl-2,3-bis-(tri-methylsilyl),cyclic methyl-boronate & 45.94 & 0.91 \\
\hline $2,2^{\prime}, 7,7^{\prime}$-Tetra bromo-9, $9^{\prime}$-spiro bi fluorenone & 45.99 & 0.72 \\
\hline 9,12,15-Octa decatrienoic acid, 2-phenyl-1,3-dioxan-5yl ester & 46.05 & 0.64 \\
\hline Flavone- 4'-OH, 5-OH, 7-dioglucoside & 58.07 & 1.07 \\
\hline Octadeca methyl cyclonona siloxane & 59.77 & 0.76 \\
\hline Acetylcodeine & 61.17 & 0.50 \\
\hline 3,9-Epoxy pregnane-11,14,18-triol-20-one,16-cyano-3-methoxy,11-acetate & 61.52 & 1.05 \\
\hline 3,5-Dibromo-4-amino biphenyl & 61.62 & 0.61 \\
\hline Dimethoxy glycerol docosyl ether & 62.40 & 0.78 \\
\hline 1,4,10,13-Tetra oxa-7,16-diaza-cyclo octa-decane, 7,16 -bis-(1-oxodecyl) & 63.07 & 0.75 \\
\hline
\end{tabular}

Table 1. GC-MS analysis of defatted soybean meal fermented with Aspergillus fumigates F-993.

\section{Discussion}

Plant extracts contain many important phytoestrogens compounds, the most relevant to human health include: phytoestrogens genistein and daidzein (from soybean), formononetin (from clover), biochanin-A (from chickpeas) and coumestans and lignans (from flaxseed). However, the majority of such compounds are naturally found, in plants, in the glycosylated form. Moreover, the bioavailability of such glycoconjugates varies from their analogous unsubstituted aglycones. In mammals, it has been documented that phytoestrogens induce oestrogenic and anti-oestrogenic effects via their weak binding to the nuclear $\alpha$ and $\beta$ oestrogen receptors (ER). In general, the relative binding affinity of phytoestrogens to $\beta$ oestrogen receptors (ER $\beta$ ) is higher than that to $\alpha$ oestrogen receptors $(\mathrm{ER} \alpha)$. It has been reported that such phytoestrogens are associated with a lower rate of steroid-hormone-dependent cancers, such as colon, prostate and breast cancer.

It has been revealed that the role played by of polyphenols against flue virus, as antiviral mechanism, can be attributed to the inhibition of its adsorption to Madin-Darby canine kidney cells ${ }^{33}$, as well as the interference in viral membrane fusion ${ }^{28}$. It is a well-known fact that mechanism of oxidative stress, commonly associated viral infections including HSV-1, plays a major role in viral replication inside the viral-infected cells. Moreover, viral replication can be inhibited through restoring the intracellular redox conditions by the help of special antioxidants (e.g., glutathione "GSH" or $n$-butanoyl derivative "GSH-C4") which inhibit HSV-1 replication ${ }^{34,35}$. In addition, Ramadan et al. 2014 have concluded that the main ingredients of the volatile compounds in DSM extracts are 23.8\% (2,3-dicyano-7,7-dimethyl-5,6-benzodiene) and $19.1 \%$ (9-ditertbutyl-1-oxaspiro-4,5-deca-6,9-diene-2,8-dione) ${ }^{1}$.

It has been concluded that the major volatile antioxidant compounds, in FDSM, were butylated hydroxytoluene and 11,14-octadecadienoic acid, methyl ester. Octadecadienoic acid has been reported to be present in Michelia champaca Linn extracts and impart antioxidant and anticancer activities to the plant extract ${ }^{36}$. Specific food additives prevent lipid oxidation and rancidity, for example Butylated hydroxyl toluene "BHT", which is the most commonly used synthetic antioxidant ${ }^{37}$. Studies have revealed that "BHT" has anticancer activities and tumour promotion effects. Moreover, its effect on other carcinogens depends on a number of factors including, the carcinogen, target organ, exposure parameters, as well as the animal being tested. The toxicity of butylated hydroxytoluene is suggested to be the result of it being an electrophilic metabolite ${ }^{38-43}$. Numerous 


\begin{tabular}{|c|c|c|}
\hline Identified compounds & Rt & Area\% \\
\hline 2-Nonadecanone & 5.46 & 0.78 \\
\hline 3,4-Pyridinediamine-6,6'-(1,3-phenylene)-2,5-diphenyl & 6.88 & 0.77 \\
\hline [(4-Phenyl-5-sulfanyl-4H-1,2,4-triazol-3yl)-methoxy]-acetic acid & 9.80 & 1.07 \\
\hline$\alpha$-Bisabolene & 10.33 & 1.47 \\
\hline 5-Bromo-3,3" $, 4,4^{\prime \prime}$-tetra butyl-2,2', $5^{\prime}, 2^{\prime \prime}$-terthiophene & 10.49 & 1.57 \\
\hline 4-Bromo phenyl-bis-(2,4-dibromo phenyl)-amine & 11.06 & 0.70 \\
\hline Di-2-benzothiazole disulfane & 11.18 & 0.70 \\
\hline 11-Octadecenal & 12.39 & 0.92 \\
\hline Methyl di-homo ç-linolenate & 13.63 & 0.68 \\
\hline Androst-5-en-4-one & 25.82 & 0.93 \\
\hline Iso-humulone & 26.96 & 0.79 \\
\hline 11,14-Octadecadienoic acid, methyl ester & 29.11 & 63.63 \\
\hline AnodendrosideA & 33.08 & 0.78 \\
\hline 2,2'-dioxospirilloxanthin & 33.74 & 0.78 \\
\hline D-prim-cortisone & 35.02 & 0.91 \\
\hline Rhodopin & 35.55 & 0.69 \\
\hline Brom thymol Blue & 41.62 & 0.77 \\
\hline Imidazole-2,4,5-d3 & 53.40 & 0.77 \\
\hline 3,5-Dihydroxy cholestan-6-one & 55.39 & 0.87 \\
\hline Anodendroside G & 55.51 & 0.96 \\
\hline Stearic acid,3-(octadecyloxy) propyl ester & 58.21 & 1.09 \\
\hline Rhodovibrin & 58.75 & 0.71 \\
\hline Dimethoxy glycerol docosyl ether & 61.17 & 1.13 \\
\hline Lucenin 2 & 62.36 & 1.09 \\
\hline Lycoxanthin & 62.92 & 0.72 \\
\hline Ponasteroside A & 63.66 & 1.27 \\
\hline
\end{tabular}

Table 2. GC-MS analysis of defatted soybean meal fermented with Aspergillus awamori FB-133.

\begin{tabular}{|l|c|c|l|}
\hline $\begin{array}{l}\text { Extracts } \\
\text { Extracts }\end{array}$ & $\begin{array}{l}\text { ABTS }(* m M \\
\text { TE/mL) }\end{array}$ & $\begin{array}{l}\text { FRAP }(* m M \\
\text { TE/mL) }\end{array}$ & $\begin{array}{l}\text { DPPH }(* * m g \\
\text { AAE } / \mathbf{m L})\end{array}$ \\
\hline DSM & $3.36 \pm 0.05^{\mathrm{a}}$ & $2.11 \pm 0.02^{\mathrm{a}}$ & $0.511 \pm 0.01^{\mathrm{a}}$ \\
\hline FDSM2 & $4.763 \pm 0.05^{\mathrm{b}}$ & $3.795 \pm 0.03^{\mathrm{b}}$ & $0.625 \pm 0.02^{\mathrm{b}}$ \\
\hline FDSM1 & $4.331 \pm 0.04^{\mathrm{b}}$ & $3.971 \pm 0.02^{\mathrm{b}}$ & $0.692 \pm 0.01^{\mathrm{b}}$ \\
\hline
\end{tabular}

Table 3. Antioxidant activity of extracts of defatted soybean meal(DSM) and defatted soybean meal fermented with Aspergillus fumigatus F-993 (FDSM1) and A. awamori FB-113 (FDSM2) measured by ABTS, FRAP and $\mathrm{DPPH}$ assays. All data are presented as mean $\pm \mathrm{SD}$. Values in the same column with the different superscripts are significant at $\mathrm{P}<0.05$. *Results are expressed as inhibitory activity in mmol Trolox equivalent $/ \mathrm{mL}$ ( $\mathrm{mM} \mathrm{TE} /$ $\mathrm{mL}$ ) of extract. **Results are expressed as inhibitory activity in mg ascorbic acid equivalent per mL (mg AAE/ $\mathrm{mL}$ ) of extract.

\begin{tabular}{|l|l|l|}
\hline Extracts & $\begin{array}{l}\text { Hepatitis A virus titre } \\
\left(\log _{10} / \mathbf{0 . 1} \mathbf{~ m L}\right)\end{array}$ & $\begin{array}{l}\mathrm{IC}_{\mathbf{5 0}}(\boldsymbol{\mu g} / \mathrm{mL}) \text { for } \\
\text { HepG2 }\end{array}$ \\
\hline DSM & $5.50 \pm 0.515^{\mathrm{a}}$ & $27 \pm 2.94^{\mathrm{a}}$ \\
\hline FDSM2 & $3.0 \pm 0.216^{\mathrm{b}}$ & $8.60 \pm 1.40^{\mathrm{b}}$ \\
\hline FDSM1 & $2.66 \pm 0.110^{\mathrm{c}}$ & $16.88 \pm 1.82^{\mathrm{c}}$ \\
\hline
\end{tabular}

Table 4. Cytotoxicity and antiviral activity of extracts of defatted soybean meal (DSM) and defatted soybean meal fermented with Aspergillus fumigatus F-993 (FDSM1) and A. awamori FB-113 (FDSM2) against HepG2 liver cancer cell line and hepatitis A virus. All data are presented as mean $\pm S D$. Values in the same column with the different superscripts are significant at $P<0.05$.

studies have revealed that Butylated hydroxyl toluene "BHT" acts as a potent antioxidant that significantly inhibits cytokine-induced inflammatory responses in both human and mouse cells ${ }^{44}$.

Although, it has been concluded that the potency of modified ester of epigallocatechin gallate against HSV-1 infections, in vitro, is greater than that of epigallocatechin gallate, yet further studies are still recommended to fully explain the exact mechanism of action taking place in humans. Though, the use of the appropriate natural 
products could improve the health status of several patients via offering much better life. Murakami et al. 2003 have reported that bis-butylated hydroxyanisole inhibits the activation of activator protein-1, and hence it could be used in the chemoprevention of oral diseases, e.g. leukoplakia and destructive chronic periodontitis ${ }^{45}$.

The transformation of isoflavone glycosides into aglycones has been suggested to be promoted by soybean fermentation, hence fermented soybean is used as an ingredient in the formulation of foods with functional properties for health benefits ${ }^{44}$. By comparing with the results of earlier studies, it was clearly seen that these major compounds have major neuroprotective, antioxidant, anti-inflammatory, anticancer, hepatoprotective, and antimicrobial effects ${ }^{46-50}$. In conclusion, our results indicate that FDSMs possess antioxidant, anticancer and antiviral properties.

Received: 13 March 2019; Accepted: 18 March 2020;

Published online: 07 April 2020

\section{References}

1. Ramadan, M. M., Elbandy, M. A., Fade, M. \& Ghanem, K. Z. Biotechnological production of volatile and non-volatile antioxidant compounds from fermented soy bean meal with Trichodermasp. Res. J. Pharm. Biol. Chem. Sci. 5, 537-547 (2014).

2. Ghanem, Z. K., Ramadan, M. M., Ghanem, H. Z. \& Fadel, M. Improving production of unsaturated fatty acid esters and flavonoids from date palm pollen and their effects as anti-breast cancer and anti-viral: In-vitro study. J. Arab Soc. Med. Res. 10, 46-55 (2015).

3. Yajie, W. \& Huimin. Tandem Reactions Combining Biocatalysts and Chemical Catalysts for Asymmetric Synthesis. Catalysts. 6(12), 194 (2016).

4. Sivakumar, T. \& Gajalakshmi, D. Phytochemical screening and GC-MS analysis of root extract from Asparagus racemosus L. Int. J. Pharmaceut. Sci. Res. 5, 1000-1005 (2014).

5. Zakir, M. \& Freitas, I. Benefits to human health in consumption of isoflavones present in soybean products. Journal of bioenergy and food science 2(3), 107-116 (2015).

6. Kim, E. H. et al. Analysis of phenolic compounds and isoflavones in soybean seeds [Glycine max (L.) Merill] and sprouts grown under different conditions. Eur. Food Res. Technol. 222, 201-208 (2006).

7. Takemoto, K. et al. Effect of Aspergillus awamori-Fermented Burdock Root on Mouse Diabetes Induced by Alloxan-Prevention of Cell Apoptosis. Food and Nutrition Sciences 05(16), 1554-1560 (2014).

8. Kaminski, E., Stawicki, S. \& Wasowicz. Volatile Flavor Compounds Produced by Molds of Aspergillus, Penicillium, and Fungi. imperfectiApplMicrobiol. 27(6), 1001-1004 (1974).

9. Wardhani, D. H., Vázquez, J. A. \& Pandiella, S. S. Mathematical modelling of the development of antioxidant activity in soybeans fermented with Aspergillus oryzae and Aspergillus awamori in the solid state. J. Agric. Food Chem. 57, 540-544 (2009).

10. Chun, J. Y. et al. Conversion of isoflavone glucosides to aglycones in soymilk by fermentation with lactic acid bacteria. J. Food Sci. 72, M39-44 (2007).

11. Lin, C. H., Wei, Y. T. \& Chou, C. C. Enhanced antioxidative activity of soybean koji prepared with various filamentous fungi. Food Microbiol. 23, 628-633 (2006).

12. Oh, D. et al. Systematic review of pediatric health outcomes associated with childhood adversity. BMC Pediatr. 18, 83 (2018).

13. Muruganantham, N., Solomon, S. M. \& Senthamilselvi, M. Anti-cancer activity of Plumeriarubra (flowers) against human liver cancer. Int. J. Pharmacogn. Phytochem. Res. 6, 1007-1009 (2014).

14. Siegel, R. L., Miller, K. D. \& Jemal, A. Cancer Statistics, 2019. Ca Cancer J. Clin. 69, 7-34 (2019).

15. Wang, Y. \& Zhao, H. Tandem Reactions Combining Biocatalysts and Chemical Catalysts for Asymmetric Synthesis. Catalysts. 6, 194 (2016).

16. Shad, A. et al. Phytochemical and Biological Activities of Four Wild Medicinal Plants. The Scientific World Journal 2014, 7 (2014).

17. Nersesyan, H. \& Slavin, K. V. Current approach to cancer pain management: Availability and implications of different treatment options. Ther. Clin. Risk Manag. 3, 381-400 (2007).

18. DeFeudis, F. V., Papadopoulos, V. \& Drieu, K. Ginkgo biloba extracts and cancer: a research area in its infancy. Fundam. Clin. Pharmacol. 17, 405-417 (2003).

19. Abd-Algader, N. N., El-Kamali, H. H., Ramadan, M. M., Ghanem, K. Z. \& Farrag, A. R. H. Xylopiaaethiopica volatile compounds protect against panadol-induced hepatic and renal toxicity in male rats. World Appl. Sci. J. 27, 10-22 (2013).

20. Ramadan, M. M., Abd-Algader, N. N., El-kamali, H. H., Ghanem, K. Z. \& Farrag, A. R. H. Chemopreventive effect of Coriandrumsativum fruits on hepatic toxicity in male rats. World J. Med. Sci. 8, 322-333 (2013).

21. Ramadan, M. M., Abd-Algader, N. N., El-kamali, H. H., Ghanem, K. Z. \& Farrag, A. R. H. Volatile compounds and antioxidant activity of the aromatic herb Anethumgraveolens. J. Arab Soc. Med. Res. 8, 79-88 (2013).

22. Ramadan, M. M., Ali, M. M., Ghanem, K. Z. \& El-Ghorab, A. H. Essential oils from Egyptian aromatic plants as anti-oxidant and novel agents in human cancer cell lines. GrasasAceites 66, e080, https://doi.org/10.3989/gya.0955142 (2015).

23. Bintsis, T. Foodborne pathogens. AIMS microbiology 3(3), 529-563 (2017).

24. Prabhakar, K. R., Srinivasan, K. K. \& Rao, P. G. M. Chemical investigation, anti-inflammatory and wound healing properties of Coronopusdidymus. Pharmaceutical Biology 40 (7) 49-493 (2002).

25. Mesquita, J. R. \& Nascimento, M. S. A foodborne outbreak of norovirus gastroenteritis associated with a Christmas dinner in Porto Portugal, December 2008. Euro Surveill. 14, 19355, https://doi.org/10.2807/ese.14.41.19355-en (2009).

26. Naga Vamsi Krishna, A., Venkata Raman, B., Kasetti Ramesh, B. \& Chippada, A. Antioxidant activity and GC-MS analysis of Phragmytesvallatoria leaf ethanolicextract. Int. Res. J. Pharm. 3, 252-254 (2012).

27. Thaipong, K., Boonprakoba, U., Crosby, K., Cisneros, L. \& Byrnec, D. H. Comparison of ABTS, DPPH, FRAP, and ORAC assays for estimating antioxidant activity from guava fruit extracts. J. Food Compos.Anal. 19, 669-675 (2006).

28. Imanishi, N. et al. Additional inhibitory effect of tea extract on the growth of influenza A and B viruses in MDCK cells. Microbiol. Immunol. 46, 491-494 (2002).

29. Arnao, M. B., Cano, A. \& Acosta, M. The hydrophilic and lipophilic contribution to total antioxidant activity. Food Chem. 73, 239-244 (2001).

30. Malencic, D., Maksimovic, Z., Popovic, M. \& Niladinovic, J. Polyphenol content and antioxidant activity of soybean seed extracts. Bioresour. Technol. 99, 6688-6691 (2008).

31. Mansouri, A., Embarek, G., Kokkalou, E. \& Kefalas, P. Phenolic profile and antioxidant activity of the Algerian ripe date palm fruit (Phoenix dactylifera). Food Chem. 89, 121-127 (2005).

32. El-Ghorab, H. A., Ramadan, M. M. \& Abd El-Moez, S. I. Essential oil, antioxidant, antimicrobial and anticancer activities of Egyptian Plucheadioscoridis extract. Res. J. Pharm. Biol. Chem. Sci. 6, 1255-1265 (2015).

33. Zhoua, Z. et al. Protocatechuic aldehyde inhibits hepatitis B virus replication both in vitro and in vivo. Antiviral Res. 74, 59-64 (2007).

34. De Chiara, G. et al. APP Processing Induced by Herpes Simplex Virus Type 1 (HSV-1) Yields Several APP Fragments in Human and Rat Neuronal Cell. PLOS ONE 5(11), e13989 (2010). 
35. Mathew, O. P., Ranganna, K. \& Yatsu, F. M. Butyrate, an HDAC inhibitor, stimulates interplay between different posttranslational modifications of histone $\mathrm{H} 3$ and differently alters G1-specific cell cycle proteins in vascular smooth muscle cells. Biomedicine \& Pharmacotherapy. 64(10), 733-740 (2010).

36. Song, J. M., Lee, K. H. \& Seong, B. L. Antiviral effect of catechins in green tea on influenza virus. Antiviral Res. 68, 66-74 (2005).

37. Hossain, M. M. et al. Antioxidant, analgesic and cytotoxic activity ofMicheliachampaca Linn. Leaf. Stamford J. Pharm. Sci. 2, 1-7 (2009).

38. Wanita, A. \& Lorenz, K. Antioxidant potential of 5-N-pentadecylresorcinol. J. Food Process. Preserv. 20, 417-429 (1996).

39. Chetverikova, L. K. et al. Factors of antiviral resistance in the pathogenesis of influenza in mice. [Article in Russian] Vestn. Akad. Med.Nauk SSSR 11, 63-68 (1989).

40. Chetverikova, L. K. \& Inozemtseva, L. I. Role of lipid peroxidation in the pathogenesis of influenza and search for antiviral protective agents. [Article in Russian] Vestn. Akad. Med. Nauk SSSR 3, 37-40 (1996).

41. Forni, C et al. Beneficial Role of Phytochemicals on Oxidative Stress and Age-Related Diseases. Biomed Research International. (2019).

42. Murakami, Y. et al. Preventive effect of ortho dimer of butylated hydroxyanisole on activator protein-1 activation and cyclooxygenase-2 expression in macrophages stimulated by fimbriae of Porphyromonasgingivalis, an oral anaerobe. Anticancer Research. 26(4B), 2915-2920 (2006).

43. Keith, A. D., Arruda, D., Snipes, W. \& Frost, P. The antiviral effectiveness of butylated hydroxytoluene on herpes cutaneous infections in hairless mice. Proc. Soc. Exp. Biol. Med. 170, 237-244 (1982).

44. Murakami, Y., Ito, S., Atsumi, T. \& Fujisawa, S. Theoretical prediction of the relationship between phenol function and COX-2/AP-1 inhibition for ferulic acid-related compounds. In Vivo 19, 1039-1044 (2005).

45. Murakami, Y., Shoji, M., Hanazawa, S., Tanaka, S. \& Fujisawa, S. Preventive effect of bis-eugenol, a eugenol ortho dimer, on lipopolysaccharide-stimulated nuclear factor kappa B activation and inflammatory cytokine expression in macrophages. Biochem. Pharmacol. 66, 1061-1066 (2003).

46. Ramadan, M. M., El-Ghorab, A. H. \& Ghanem, K. Z. Volatile compounds, antioxidants and anticancer activities of Cape gooseberry fruit (Physalisperuviana L.): In vitro study. J. Arab Soc. Med. Res. 10, 56-64 (2015).

47. Wadl, M. et al. Food-borne norovirus-outbreak at a military base, Germany, 2009. BMC Infect. Dis. 10, 30, https://doi. org/10.1186/1471-2334-10-30 (2010).

48. Zomer, T. P. et al. A foodborne norovirus outbreak at a manufacturing company. Epidemiol.Infect. 138, 501-506 (2010).

49. Bourinbaiar, A. S. \& Jirathitikal, V. Low-cost anti-HIV compounds: potential application for AIDS therapy in developing countries. Curr.Pharm. Des. 9, 1419-1431 (2003).

50. Murakami, Y. et al. Dehydrodiisoeugenol, an isoeugenol dimer, inhibits lipopolysaccharide-stimulated nuclear factor kappa B activation and cyclooxygenase-2 expression in macrophages. Arch. Biochem. Biophys. 434, 326-332 (2005).

\section{Acknowledgements}

The authors really express their deep thanks and gratitude to the Scientific Research Deanship of King Saud University, Riyadh, Kingdom Saudi Arabia for their fruitful support through funding the present study.

\section{Author contributions}

K.G., M.R., M.Z.M. and H.G. carried out the antioxidant analysis, GC-MS analysis, fermentation experiments, results preparation and participation in the manuscript drafting. M.F. carried out the anticancer and antiviral Analysis. K.G., M.R. and M.H.M. put the study design, performed the statistical analysis, and participated the manuscript drafting.

\section{Competing interests}

The authors declare no conflicts of interest, state that the manuscript has not been published or submitted elsewhere, state that the work complies with the Ethical Policies of the Journal and state that the work has been conducted under internationally accepted ethical standards after relevant ethical review.

\section{Additional information}

Correspondence and requests for materials should be addressed to M.H.M.

Reprints and permissions information is available at www.nature.com/reprints.

Publisher's note Springer Nature remains neutral with regard to jurisdictional claims in published maps and institutional affiliations.

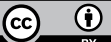

Open Access This article is licensed under a Creative Commons Attribution 4.0 International License, which permits use, sharing, adaptation, distribution and reproduction in any medium or format, as long as you give appropriate credit to the original author(s) and the source, provide a link to the Creative Commons license, and indicate if changes were made. The images or other third party material in this article are included in the article's Creative Commons license, unless indicated otherwise in a credit line to the material. If material is not included in the article's Creative Commons license and your intended use is not permitted by statutory regulation or exceeds the permitted use, you will need to obtain permission directly from the copyright holder. To view a copy of this license, visit http://creativecommons.org/licenses/by/4.0/.

(c) The Author(s) 2020 